\title{
CHANGES IN MENTAL HEALTH AFTER COVID-19 TRANSFER AND HEALTH CARE RESOURCES
}

\author{
Valentina Chorna \\ Ph.D., Associate Professor, National Pirogov Memorial Medical University, Ukraine \\ e-mail: valentina.chorna65@gmail.com,orcid.org/0000-0002-9525-0613

\section{Volodymyr Podolian} \\ Ph.D., Associate Professor, National Pirogov Memorial Medical University, Ukraine \\ e-mail: v.podolyanvin@ukr.net, orcid.org/0000-0002-1130-4400
}

\section{Summary}

The article analyzes the incidence of COVID-19 and complications after the disease, especially in terms of the mental health of the world's population. The purpose of the study was to analyze changes in the mental health of the population of Ukraine after the transfer of COVID-19 and determine the resources of health professionals in the field of health, summarize the most common complaints that arose during the disease, identify compliance with quarantine measures and duration of treatment as in the hospital and at home, in the systematization of complications after the disorder, the duration of antidepressants and the assessment of respondents' attitudes towards vaccination against COVID-19. A sociological survey has been conducting of 611 respondents mostly students, and teachers of Vinnytsia National University Pirogov. According to the results of the questionnaire, complaints from the nervous system: fatigue $-85.6 \%$, sleep disorders during the disease were noted $-41.4 \%$, irritability $-38.6 \%$, anxiety disorders $-26.0 \%$, memory impairment $-23,2 \%$, depression $-17.9 \%$, fear $-13.3 \%$, confusion $-11.9 \%$, panic attacks $-10.2 \%$, convulsions $-4.9 \%$ and suicidal thoughts in $2.1 \%$ (66.6\% of men) respondents. In Ukraine, it is necessary to create new conditions for alternative treatment of the mentally ill and the population that has negative consequences in mental health after the transfer of COVID-19 based on primary health care, namely: in psychiatric wards of general hospitals, day hospitals, in crisis centers, mental health centers. It is necessary to create a single electronic medical system for recording appeals from the public (personal data) to improve the health care system, as is done in European countries.

Keywords: pandemic, mental disorders, quarantine, isolation, depression.

\section{DOI https://doi.org/10.23856/4334}

\section{Introduction}

Prolonged quarantine due to the COVID-19 pandemic has affected the mental health of people in 188 countries. A speech by WHO Director-General Tedros Adhan Gebreesus noted the importance of the COVID-19 pandemic's impact on the mental health of millions of people on the planet who have fallen ill and have been quarantined or isolated for a long time. According to scientists from many countries, there have been changes not only in the respiratory system a characteristic respiratory syndrome but also in changes in mental health. Thus, according to Nasir Mustafa, Carod-Artal F.J., Garg R.K. $-52.7 \%$ of respondents rated the impact of the pandemic as «severe»; the presence of symptoms of depression has been finding in $18.6 \%$ of respondents; anxiety symptoms in 26.5\%; high levels of stress as a result of COVID-19 disease, 
concerns about their health and loved ones, financial losses due to quarantine restrictions in 7.9\% of respondents (Carod-Artal F.J.,2020; Gard R.K., 2020; Mustafa N., 2020).

Mental health disorders in the world are the chief causes of disability and significant burdens for any state in financial, economic, and social policy. The WHO is constantly working to prevent depression, anxiety, stress, and suicide due to epidemiological data that 5 to $7 \%$ of the world's population suffers from the mental illness of the COVID-19 pandemic. The WHO predicted that by 2020 , mental illness worldwide would increase to $50 \%$ of all diseases but did not expect chief consequences from the COVID-19 pandemic. At the same time, according to the WHO, before the start of the COVID-19 pandemic in Ukraine, 628 new cases of mental illness were registered each year (per 100,000 population), and no less predominate environmental/anti-terrorist operation in the east of the country (Gladun Z.S., 2005; Korol 'chuk O.L., 2016).

The shortage of health workers in the EU has always been an acute problem, especially in the field of mental health (psychiatrists, neurologists, psychologists) as in Ukraine. Thus, according to Satiani A. (2018), in the United States by 2024, the deficit of the number of psychiatrists to the population will be between 14,280 and 31,091, according to Hadlaczky G. (2012), the number of practicing psychiatrists in Sweden has decreased, and therefore 5-10\% of the population needs psychiatric treatment, and only 3-4\% seek psychiatric help, and about 10 million Swedes commit suicide each year (Hadiaczky G. et el., 2012; Satiani A. et el., 2018; Sun J., Sun R. et el., 2020).

The aim - to analyze the changes in the mental health of the population of Ukraine after the transfer of COVID-19 and determine the resource of health professionals in the field of health, summarize the most common complaints that arose during the disease, identify compliance with quarantine measures and duration of treatment in hospital and at home, to systematize the occurrence of post-disease complications, the duration of antidepressant use, and to assess respondents' attitudes toward COVID-19 vaccination.

\section{Materials and methods}

611 respondents mostly students and teachers of National Pirogov Memorial Medical University, took part in the optional anonymous sociological survey, aged 17 to 23 years $68.6 \%$, from 23 to 30 years $-19.0 \%$, from 30 to 45 years $-6.2 \%$ and over 45 years $-6.2 \%$. Of all respondents, women accounted for $77.9 \%$ and $22.1 \%$ of males, respectively. Statistical processing of the survey results has been performing in the licensed standardized package «Statistica 6.1 for Windows» and Excel-2010. The analysis of domestic and foreign scientific sources, biblio-semantic and analytical research methods have been also using in the work.

\section{Results and discussion of indicators of morbidity and prevalence of the disease}

In recent years, the incidence and prevalence of diseases and disabilities in Ukraine have increased with a catastrophic decrease/reduction in the number of doctors of all specialties for the period $1995 / 2015$ at $3.1 \%$, and for $2010 / 2017$ by $10.5 \%$ (10 thousand population) and nurses for the period $1995 / 2015$ at $25.1 \%$, and $2010 / 2017$ by $16.6 \%$ (10 thousand population); the number of health care hospitals decreased during the period 1995/2015 at 53.8\%, and for $2010 / 2017$ - by $39.3 \%$ (thousand units) and the number of hospital beds decreased during the period $1995 / 2015$ at $37.6 \%$, and for $2010 / 2017$ by $22.2 \%$ respectively (10 thousand population). And among psychiatrists and psychiatrists-narcologists per 10 thousand population for the period $1995 / 2015$ at $15.4 \%$, and for $2010 / 2017$ by $21.4 \%$, respectively, since the beginning of the JFO (OOS)/ATO in the East of the country since 2014, the number 
of patients with mental disorders has increased, who needed the help of psychiatrists, narcologists, psychologists. The second fatalistic side of the health care reform is the lack of funding for the outdated material and technical base of psychiatric hospitals built in the XVIIIXIX centuries, which contradicts the solution requirements of the mental health system in European countries and does not allow to create of a «therapeutic environment» (Chorna V.V. et el., 2020: 150; Chorna V.V. et el., 2020: 8). According to the results of the survey, we found that out of 611 respondents $-47.5 \%$ became ill with COVID-19, of which $11.0 \%$ were male, and $36.4 \%$ were female.

According to Komisarenko S.V., there are three types of COVID-19 virus: A, B, C. It depends on the nucleotide sequence Sequencing is a method that determines the sequence of nucleotides (DNA and RNA), but unfortunately in Ukraine, this is not yet possible, as it depends on the funding of research institutes. We can assume that the population of Ukraine suffers from different strains of COVID-19 from the answers of respondents how many times they were sick, the data are as follows: 1 time fell ill $-91.5 \% 2$ times $-7.5 \%$ and $1 \%$ of respondents fell ill three times. The following data have been establishing from the analysis of scientific works (see table № 1) (Komisarenko S.V., 2020).

The dynamics of the spread of the disease, fatalities caused by various pathogens of the coronavirus

\begin{tabular}{|c|c|c|c|c|c|}
\hline $\begin{array}{c}\text { Year of } \\
\text { registered } \\
\text { pandemic }\end{array}$ & $\begin{array}{c}\text { The causative } \\
\text { agent of the } \\
\text { disease }\end{array}$ & $\begin{array}{c}\text { The number } \\
\text { of countries } \\
\text { covered }\end{array}$ & $\begin{array}{c}\text { The number } \\
\text { of cases }\end{array}$ & $\begin{array}{c}\text { The number } \\
\text { of fatalities }\end{array}$ & $\begin{array}{c}\% \text { of } \\
\text { fatalities }\end{array}$ \\
\hline $2002-2004$ & $\begin{array}{c}\text { Virus SARS- } \\
\text { CoV (civet) }\end{array}$ & 37 & 8422 & 916 & $10,9 \%$ \\
\hline $2012-2018$ & $\begin{array}{c}\text { MERS-Cov } \\
\text { (camels) }\end{array}$ & 26 & 2519 & 866 & $34,4 \%$ \\
\hline 32019 p. & SARS-CoV-2 & 188 & $\begin{array}{c}\text { The number } \\
\text { is constantly } \\
\text { increasing } \\
\text { today to } \\
119 \text { million. }\end{array}$ & $\begin{array}{c}\text { The number } \\
\text { is constantly } \\
\text { increas- } \\
\text { ing today } \\
2.64 \text { million. }\end{array}$ & $11-12 \%$ \\
\hline
\end{tabular}

$72.5 \%$ of respondents had a mild severity, $23.7 \%$ had a moderate severity, and $3.8 \%$ had a severe severity. According to data (Petri W. (2020), in 7 countries, $40 \%$ of respondents had mild symptoms of the disease. All data depend on the epidemiological situation during the observation (Petri W., 2020).

Complaints that respondents indicated in the anonymous questionnaire were as follows: from the respiratory system - cough has been finding in $52.3 \%$ (76\% in women and $24 \%$ in men), nasal congestion in $48.8 \%$ (81\% in women and $19 \%$ in men), difficulty breathing in $28.1 \%$ (67\% in women and $13 \%$ in men) and fever in $54.7 \%(72.0 \%$ in women and $28.0 \%$ in men). The data are shown in Figure 1.

As a result of the analysis of respondents' complaints from the nervous system: fatigue was noted in $85.6 \%$, sleep arrhythmia during the disease was noting in $41.4 \%$, irritability in $38.6 \%$, anxiety disorders in $26.0 \%$, memory impairment $23.2 \%$, depression $17.9 \%$, fear $13.3 \%$, confusion $11.9 \%$, panic attacks $10.2 \%$, seizures $4.9 \%$ and suicidal thoughts $2.1 \%(66.6 \%$ in men). Respondents' data have been presenting in Figure 2. 


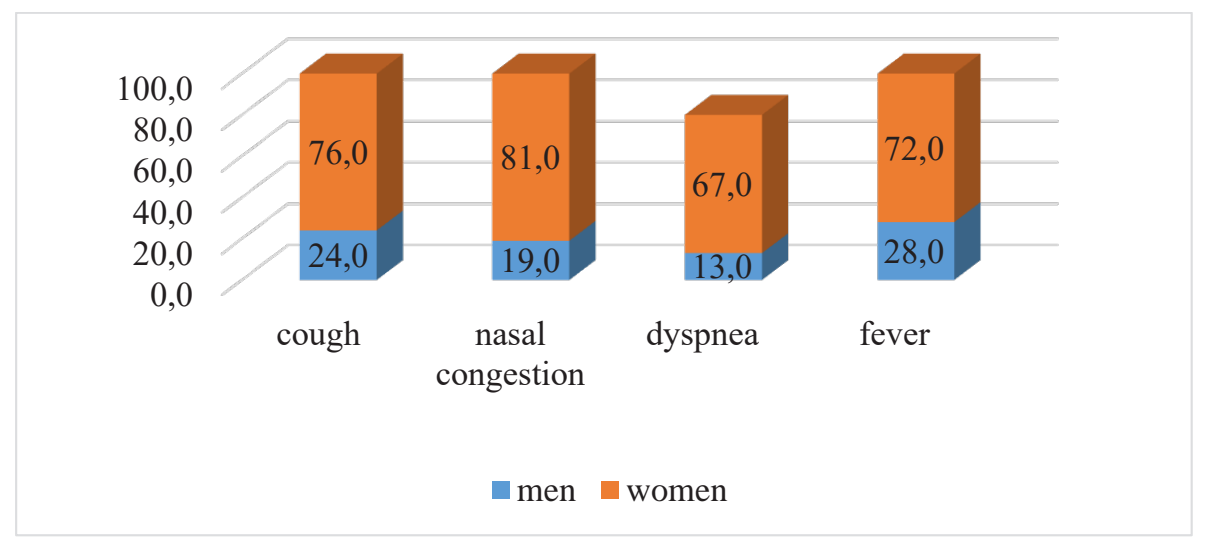

Figure 1. The proportion of complaints of patients with COVID-19, (\%)

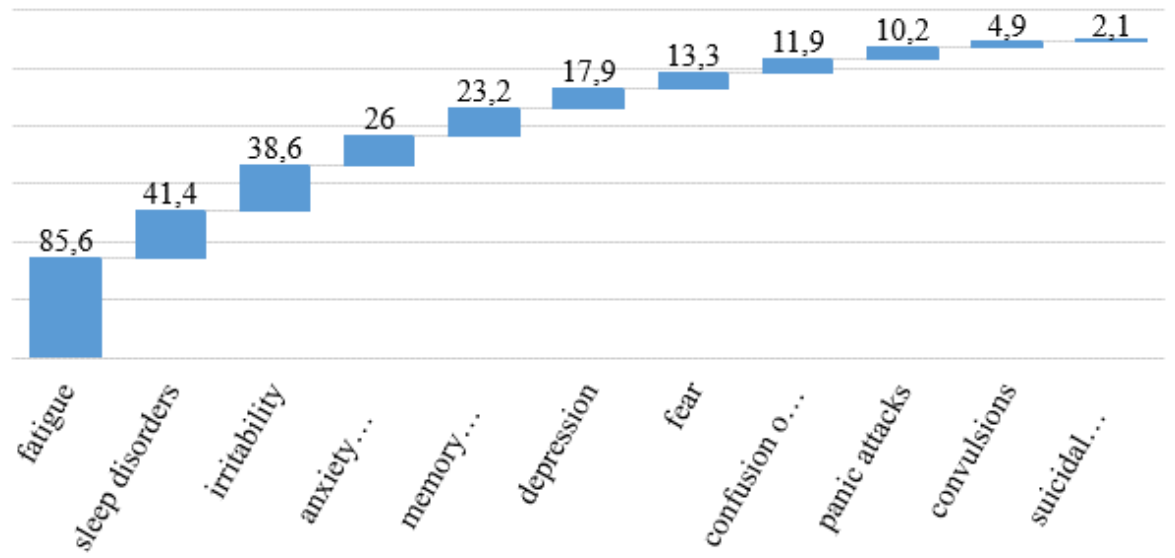

\section{Figure 2. The proportion of mental health disorders after COVID-19 transfer, (\%)}

More frequent changes in mental health have been noting by women in both Ukraine and the EU. According to EU scientists, there were mental health disorders in the form of stress in $22.8 \%$, maladaptation in $21.8 \%$, anxiety disorders in $20.8 \%$, depression in $17.3 \%$, sleep disorders in $7,3 \%$ of respondents. The World Federation of Neurology has proposed the introduction of international neurological registries and international neuro-epidemiological cooperation to help identify the problem of neurological disorders (Roman G.C. et el., 2020).

Symptoms such as loss of taste and smell in COVID-19 patients with 59.9\% of respondents noted in themselves, namely: $47 \%$ - female and $15.2 \%$ - male, and this symptom is specific to COVID-19. Polymerase chain reaction (PCR) tests from all sick respondents showed a positive result in $20.2 \%$, negative in $18.6 \%$, and did not pass this test $-61.2 \%$ due to the high cost. According to research by Liuqian L. (2020), 14\% of patients after hospital discharge from COVID-19 with negative PCR test results after recovery had a positive outcome after some time (Liuqian L. et el., 2020). Blood test for IgG-class antibodies from sick respondents has been doing by only $31.3 \%$, they appear on the $24-28$ th day in each patient with COVID-19, 
their number varies depending on many factors and can remain in the human body both from several months and years (Hadiaczky G. et el., 2012).

$43.4 \%$ of respondents sought medical help from a family doctor, $28.7 \%$ treated themselves and $27.9 \%$ did not take any medication due to the mild course of the disease. Of the complications indicated by the respondents, these are mostly disorders of the nervous system $-63.9 \%$, from the respiratory system $-33.9 \%$, from the gastrointestinal tract $-26.7 \%$. On the side of mental health disorders, patients have been forcing to turn to psychiatrists who prescribed antidepressants. The duration of antidepressants up to 14 days was noted $-47.7 \%$ (66.6\% - women), up to 1 month $-25.0 \%$ (81.8\% - women), up to 2 months $-6.8 \%$ (of which $100 \%$ - women), more than 2 months - 20.5\% of respondents (77.7\% of them - women). According to scientists for the month (from 15.02.2020 to 15.03.2020) prescriptions for antidepressants increased by $18.6 \%$ and sleeping pills by $14.8 \%$ in European countries (Mosolov S.N., 2020). According to the results of the questionnaires, the respondents needed medical care the most $-41.3 \%$, psychological $-32.7 \%$, information $-20.9 \%$, and $32.7 \%$ - noted the need for help from relatives. And the last question for the respondents was about their attitude to the vaccination against COVID-19. Of all 611 respondents $-17.9 \%$ are ready to receive vaccinations, $30.5 \%$ - flatly refused, and $51.6 \%$ - have doubts about the quality of the vaccine.

Vaccination has been currently carrying out in many countries, but its effectiveness has also been studying (Komisarenko S.V., 2020).

\section{Conclusions}

Millions of people around the world have been severely damaging by the COVID-19 pandemic, which has become a global socio-economic problem. The consequences are catastrophic and require global action, especially in the field of healthcare in Ukraine and around the world.

Carrying out the reform in the field of mental health care in Ukraine according to the experience of EU countries: with reduced places in psychoneurological hospitals (deinstitutionalization) of Ukraine, it is necessary to create new conditions for alternative treatment of mentally ill people -19 based on primary health care, psychiatric wards in general hospitals, day hospitals, crisis centers, mental health centers and the creation of a single electronic register of appeals of the population of Ukraine to improve the provision of medical care.

Conflict of interest. The authors declare no conflict of interest.

\section{References}

Carod-Artal F.J. (2020). [Neurological complications of coronavirus and COVID-19]. Revista de Neurologia. 70(9):311-322. doi: https://doi.org/10.33588/rn.7009.2020179

Chorna V.V., Makhniuk V.M., Gumeniuk N. \& Tomashevskyi A. (2020). Comparative analysis of morbidity indicators among the population of the eu and Ukraine under conditions of stressed load of the Anti-terrorist operations and psych prophylaxis measures. Georgian medical al news. 5 (302).147-154

Chorna V. V., Makhniuk V. M., Khliestova S. S. \& Gumeniuk N.I. (2020). [Assessment of the quality of medical services to relatives of the mentally ill who are in inpatient treatment]. Biomedical and Biosocial Anthropology (Official Journal of the International Academy of Integrative Anthropology), 38, 5-11 DOI: https://doi.org/10.31393/bba38-2020-01 
Gard R.K. (2020). [Spectrum of neurological manifestations in COVID-19: A review]. Neurology India. 68(3):560-572. doi: https://doi.org/10.4103/0028-3886.289000

Gladun Z.S. (2005). [Derzhavna polituka okhoroni zdorovya v Ukrayini: monografiya] Z.S. Gladun. Ternopil : Ekon.dumka. 460c.[in Ukrainian]

Hadiaczky G., Stefenson A., Wasserman D. (2012). [The state of psychiatry in Sweden]. International Review of Psychiatry. 24(4):356-362. doi: https://doi.org/10.3109/09540261.2012.6 90338

Komisarenko S.V. (2020). [Polyuvannya vchenikh na koronovirus SARS-COV-2, shcho viklikaye COVID-19: naukovi strategiyi podolannya pandemiyi]. Visnik NAN Ukrayinu, 8, 29-71. doi: https://doi.org/10.15407/visn2020.08.029. [in Ukrainian]

Korol chuk O.L. (2016). [Okhorona psikhichnogo zdorovya v umovakh vedennya ATO]. Investicziya: praktika ta dosvid. 18. 96-109. [in Ukrainian]

Liuqian L., Shulun H., Wie H. (2020). [14\% of Recovered COVID-19 Patients in Guangdong Tested Positive Again]. https://www.caixinglobai.com/2020-02-26/14-of-recovered-covid-19patients-in-guangdong-tested-positive-again-101520415.html

Mosolov S.N. (2020). [Aktualnye zadachi psikhiatricheskoj sluzhby`v svyazi s pandemiej COVID-19]. Sovremennaya terapiya psikhicheskikh rasstrojstv. 2. doi: https://doi.org/10.21265/ PSYPH.2020.53.59536 [in Russia]

Mustafa N. (2020). [Psychological stress and associated factors during the coronavirus disease (COVID-19)]. International Journal of Science and Research, vol. 10, no. 4, p. 12-18.

Petri W. (2020). [Infected with the coronavirus but not showing symptoms? A physician answers 5 questions about asymptomatic COVID-19]. The Conversation. https://theconversation.com/ infected-with-the-coronavirus-but-not-showing-symptoms-a-physician-answers-5-questionsabout-asymptomatic-covid-19-137029

Roman G.C., Spencer P.S., Jacques Reis \& Wasay M. (2020). [The neurology of COVID-19revisited: A proposal from the Environmental Neurology Specialty Group of the World Federation of Neurology to implement international neurological registries]. Journal Neurol Sci. 414:116884. doi: https://doi.org/10.1016/j.jns.2020.116884

Satiani A., Niedermier J., Satiani B., Svendsen D. (2018). [Projected workforce of psychiatrists in the United states: a population analysis]. Psychiatr Serv. 69(6): 710-713. doi: https:// doi.org/10.1176/fppi.ps.201700344

Sun J., Sun R., Jiang Y., \& Zhang L. (2020). [The relationship between psychological health and social support: Evidence from physicians in China]. PLoS One. 15(1):e0228152. doi: https:// doi.org/10.1371/journal.pone.0228152.eCollection 2020 